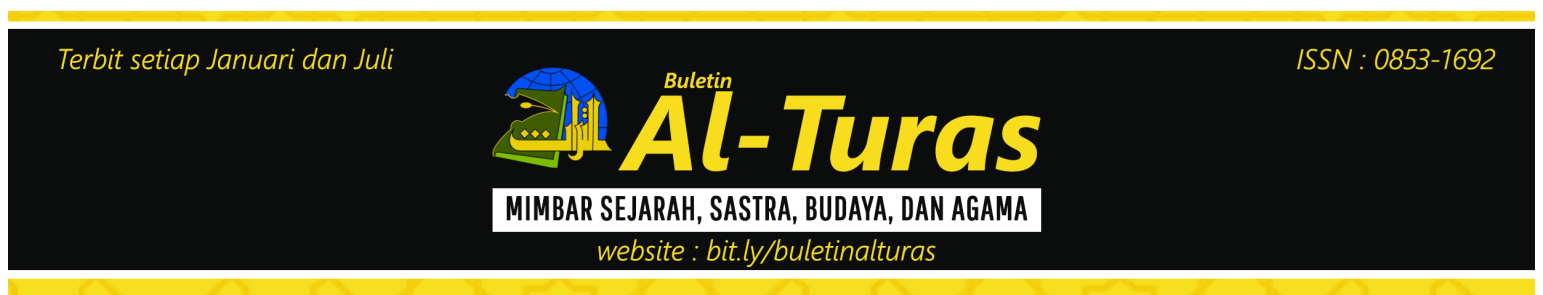

\title{
Pergeseran Peran Anak sebagai Agen Pengubah Struk- tur dalam Ekranisasi The Giver
}

\author{
Nor Islafatun ${ }^{1}$
}

\begin{abstract}
The objectives of this research is to analyze the changes or differences which happens in the adaptation of The Giver related to domination and the resistance to change a structure of society. This reseach used qualitative approach and applied the theory of adaptaion, children's literature, and symbolic violence. The adaptation of The Giver changes the subject who become agent of change, from children to teenagers or young people. In addition, it coveys modernization elements. In fact, modernizations gives two impacts to the domination practice. In one side it is able to reduce domination and on the other side it supports the domination practice. However, as represented in The Giver, dominated people always have chance to resist the domination. In addition, the resistance is easier to be done by young people rather than children. It is not only young men who can do resistance, but also young women.
\end{abstract}

Keywords: domination, adaptation, The Giver, resistance, children's literature.

\section{Abstrak}

Makalah ini bertujuan menganalisis perubahan-perubahan yang terjadi dalam ekranisasi The Giver terkait dominasi dan resistensinya untuk mengubah struktur masyarakat. Penelitian ini menggunakan pendekatan kualitatif dan teori alih wahana, sastra anak, serta kekerasan simbolik.Sebagai temuannya,terdapat perubahan peran anak sebagai agen pengubah struktur dalam ekranisasi The Giver. Jika dalam novel perubahan struktur dipercayakan pada anak-anak, dalam film peranan itu diberikan kepada remaja atau anak muda. Ekranisasi ini memasukkan unsur modernisasi dan modernitas itu sendiri menyisakan hubungan tarik-menarik terhadap praktik dominasi. Pada satu sisi modernitas mereduksi praktik dominasi, tapi di sisi lain justru semakin mendukungnya. Namun, sebagaimana direpresentasikan dalam ekranisasi The Giver, seberapapun kerasnya praktik dominasi beroperasi, selalu ada peluang pihak terdominasi untuk melawan demi menciptakan tatanan baru yang lebih baik. Perlawanan itu efektif ketika dilakukan anak muda ketimbang anak-anak. Tidak hanya oleh remaja laki-laki, tapi perlawanan atas dominasi juga sangat potensial dilakukan oleh remaja perempuan.

Kata Kunci: dominasi, ekranisasi, The Giver, resistensi, sastra anak.

\footnotetext{
${ }^{1}$ Universitas Indonesia, norislafatun@gmail.com
} 


\section{A. Pendahuluan}

Sejak diterbitkan pada tahun 1993, The Giver menarik banyak perhatian pembaca. Novel anak ini bercerita tentang kehidupan sebuah komunitas yang sempurna. Pemegang kebijakan (The Commitee) dalam komunitas tersebut mengeliminasi segala bentuk perbedaan dalam masyarakatnya supaya komunitas tersebut aman dan terhindar dari konflik. Masyarakatnya tidak mempunyai pilihan dalam hidupnya. Mereka tidak mengenal emosi, seperti rasa sakit atau sedih. Mereka juga tidak bisa menikmati kesenanangan seperti melihat warna, mendengarkan musik, atau merasakan cinta. Kehidupan dalam komunitas itu teratur dan dapat ditebak.

Pada mulanya, novel ini mendapat penolakan dari masyarakat karena dianggap terlalu provokatif. Namun, justru kekuatan cerita dantema di dalamnya menghantarkan The Giver memperoleh banyak penghargaan. The New York Timejustru menilai tema yang provokatif dalam novel ini sebagai sebuah keunggulan. A powerful and provocativenovel, demikian tulisnya sebagaimana termuat dalam lembar endorsmentnovel The Giver.Sementara itu, The Horn Book Magazinememujibahwa temakeseimbangan antara kebebasan dan keamanan dalam novel ini berhasil dinarasikan dengan sangat baik. Pada tahun 1994, novel karangan Lois Lowry, seorang penulis Amerika ini bahkan meraih penghargaan bergengsi di dunia sastra anak, yaitu Newberry Medal.

Dua puluh satu tahun berselang, di tahun 2014 sutradara Philip Noyce melakukan alih wahana novel ini ke dalam sebuah film dengan judul yang sama. Dalam wawancara yang dilakukan Jessica Gros, seorang wartawan
New York Time (Agustus, 2014) kepada Lois Lowry, Lowry menerangkan bahwa ide ekranisasi ini sebenarnya sudah muncul sejak awal novel itu diterbitkan. Dalam proses pembuatannya, Lowry mengaku tidak banyak terlibat. Ia hanya hadir sebagai pengamat atau sesekali memberikan pendapatnya mengenai film tersebut.

Setelah mengalami proses ekranisasi, The Givertermasukdalam alih wahana kritis yang mengalami beberapa perubahan, tapi masih mempertahankan garis besar teks asli (Maurey, 2008). Secara garis besar alih wahana ini masih menghidupkan isu utama berupa dominasi yang dilakukan The Commiteeterhadap masyarakat yang tinggal dalam komunitas tersebut. Dominasi itu dilakukan melalui penanaman seperangkat wacana dan aturan yang dibuat The Commitee untuk komunitas tersebut. Wacana dan aturan tersebut kemudian diterima oleh masyarakat sebagai sebuah kebenaran yang memang sudah seharusnya demikian. Mereka mematuhi aturan-aturan tersebut tanpa pernah mempertanyakan mengapa peraturan tersebut harus mempertanyakan mengapa aturan tersebut harus dibuat. Bourdieu (1997: 141) mengistilahkan fenomena seperti ini sebagai kekerasan simbolik.

Menurut Hutcheon dan O'Flynn (2006: 10), tema adalah struktur narasi (story elements) yang paling mudah diadaptasi dalam berbagai media, bahkan genre. Ekranisasi The Giver mempertahankan isu dominasi berupa kekerasan simbolik, sebagaimana yang diuraikan di paragraf sebelumnya.Tidak sebatas memotret isu dominasi, The Giver juga menghadirkanupaya perlawanan atau resistensi terhadap dominasi tersebut. Perlawanan tersebut dilakukan oleh 
beberapa tokoh yang berperan sebagai agen pengubah struktur masyarakat tersebut. Dalam proses resistensi inilah perubahan-perubahan dalam ekranisasi The Giver banyak ditemukan.

Perubahan-perubahan tersebut tentu membawa misi dan ideologi tersendiri. Tulisan ini akan mengupas makna beberapa perubahan yang terjadi dalam ekranisasi The Giver, khususnya yang dilakukan sebagai resistensi untuk mengubah struktur masyarakat yang ada dalam komunitas tersebut.

\section{a) Rumusan Masalah}

Setiap produk alih wahana mempunyai keunikannya sendiri dan tidak bisadinilai sebagai sebuah karya turunan. Perbedaan di antara dua karyamengusung ideologi berbeda. Demikian halnya dengan ekranisasi The Giver. Terdapat perbedaan di antara novel dan film The Giver.Berbeda dengan novelnya, film The Giverbanyak memasukkan unsur modernisasi. Ada beberapa scene dalam film yang memasukkan teknologi baru yang tidak bisa ditemukan dalam buku, misalnya droneyang digunakan The Commitee untuk mengawasi aktivitas komunitas, motor yang digunakan Jonas melarikan diri, scan kornea mata yang digunakan sebagai alat deteksi diri ketika Jonas memasuki ruang pelatihan, dll.

Selain adanya perubahandalam hal modernisasi, perubahan juga dapat ditemukan dalam struktur narasi cerita. Pertama, film ini mengalami "peremajaan" tokoh. Dalam novel dikisahkan bahwa Jonas, Fiona, dan Asher adalah anak-anak berumur 11 tahun, sementara dalam film usia tokoh ini menjadi 16 tahun. Para tokoh ini tidak lagi menjadi anak-anak, melainkan remaja atau anak muda. Peremajaan tokoh ini tentu saja memengaruhi perubahan karakterisasi tokoh. Masalah yang mereka hadapi tidak sesederhana anak-anak, tapi ada juga bagian-bagian yang menunjukkan masalah remaja seperti kecemburuan antara lawan jenis, cinta segitiga, dll.

Di antara perubahan karakterisasi tokoh-tokoh tersebut, tokoh perempuan Fiona mengalami perubahan watak yang signifikan dalam film. Berbeda dengan di novel, dalam film Fiona ditunjukkan mempunyai peran besar dalammembantu perjuangan Jonas mengubah struktur masyarakat. Dari sisi alur cerita,ekranisasi The Giverjuga mengalami perubahan signifikan, khususnya dalam ending cerita. Novel The Giver mempunyai ending terbuka, sementara filmnya mempunyai ending tertutup berupahappy ending.

Perubahan-perubahan tersebut mempunyai makna yang menarik untuk diteliti lebih jauh. Dunia yang kian modern rupanya tidak lantas menghilangkan praktik dominasi. Namun, di sisi lain produk modernisasi berupa teknologi juga mempermudah manusia berjuang melawan dominasi tersebut. Perubahan dalam penokohan dan alur pada ekranisasi The Giver tentu mempunyai makna tertentu berkaitan dengan upaya resistensi terhadap dominasi.

\section{b) Tujuan Penelitian}

Makalah ini bertujuan menganalisisperubahan-perubahan yang terjadi dalam ekranisasi The Giver terkait dominasi dan resistensinya untuk mengubah struktur atau tatanan masyarakat. 


\section{c) Tinjauan Pustaka}

Penelitian yang membahas novel The Giver sudah terbilang banyak dilakukan. Marshall George, seorang profesor di FordhamUniversity pada tahun 2004 telah melakukan penelitian terhadap lima novel yang memenangkan Newberry Medal pada tahun 19942000, salah satunya adalah The Giver. Penelitian ini dilakukan untuk mengetahui perbedaan respons pembaca anak dan dewasa mengenai kelima novel tersebut.Temuan dalam penelitian ini membuktikan bahwa pembaca dewasa nampak lebih bisa melihat kompleksitas tema yang beragam dalam novel tersebut, seperti utopian, individuallity, sejarah, budaya, suntik mati, dll.

Selain itu, Angela Beumer Johnson, Jeffery W. Kleismit, dan Antje J. Williams juga pernah melakukan penelitian dalam novel The Giverpada tahun 2001. Penulis yang merupakan pengajar di Wright State University melakukan penelitian ini dengan tujuan melihat refleksianak-anakpada novel The Giver dengan serangan teroris 11 Septetember di Amerika. Penelitian menunujukkan bahwa ada hubungan paralel antara kehidupan dalam The Giver dengan kehidupan nyata anak-anak di Amerika pascaserangan 11 September. Pengalaman atas serangan itu membangunkan anak-anak dari rasa kepuasan terhadap diri sendiri, sebagaimana kehidupan yang direpresentasikan dalam The Giver sebelum Jonas mengembalikan seluruh memori tentang masa lalu ke masyarakatnya.

Penelitian lain juga pernah dilakukan Gross M. pada tahun 1999. Fokus penelitian ini adalah menunjukkan bahwa pengacuhan dan pembunuhan terhadap anak-anak di negara berkem- bang masih sering terjadi, sementara perhatian yang diberikan masyarakat terhadap masalah tersebut masih minim. Melalui ceritanya,The Givermenunjukkan bahwa usaha memperoleh keadilan bagi anak-anak bisa dicapai, sebagaimana direfleksikan melalui tokoh Jonas.

Sementara itu, dengan menggunakan pendekatan reader respons, Lea Susan G. dari University of Pennsylvania dalam penelitiannya di tahun 2006 menemukan kehidupan distopia dalam The Giverbisa dimaknai sebagai metafora rasisme. Selain itu, penulis juga menemukan bahwa kehidupan hitam-putih dalam The Givermerupakan potret konsekuensi dari sikap mental manusia yang menutup diri tehadap perbedaan orang lain.

Meskipun sudah ada banyak penelitian tentang novel The Giver, penelitian The Giver dengan menggunakan pendekatan alih wahana atau ekranisasimasih sulit ditemukan. Penelitian ini berbeda dengan penelitian-penelitian sebelumnya karena akan menganalisis ekranisasi The Giver. Sebagaimana disebutkan di atas, penelitian ini akan berfokus pada perubahan-perubahan yang terjadi dalam ekranisasi The Giver terkait dengan upaya resistensi atas dominasi yang diterima masyarakat dalam komunitas The Giver.

\section{d) Landasan Teori}

Untuk melakukan analisis ekranisasi The Giver, penulis menggunakan beberapa landasan teori. Karena penelitian ini merupakan studi ekranisasi, penulis menggunakan pendekatan alih wahana dari buku Alih Wahana karya Sapardi Djoko Damono (2014). Damono (20014: 13) menjelaskan bahwa alih wahana merupakan perubahan 
suatu karya dari satu wahana ke wahana lainnya. Perubahan wahana tersebut memungkinkan terjadinya perubahan konten maupun bentuk teks karena adanya penyesuaian pada ketentuan-ketentuan wahananya yang baru.

Terkait dengan bahasan mengenai dominasi, kekerasan simbolik, dan resistensinya, penulis menggunakan teori dominasi Piere Bourdieu. Bourdieu (1998: 7) menjelaskan bahwa keinginan satu pihak melakukan dominasi terhadap pihak lain melahirkan kekuasaan simbolik yang akhirnya melahirkan bentuk-bentuk kekerasan simbolik. Lebih lanjut, menurut Bourdieu (1992) dominasi merupakan akar dari lahirnya kekerasan, sedangkan tujuan dari dominasi itu sendiri adalah kelanggengan kekuasaan.

The Giver merupakan karya sastra anak, oleh karenanya penulis juga menggunakan pendekatan sastra anak dalam menganalisis penelitian ini. Penulis menggunakan teori sastra anak dari Rebbeca J. Lukens dalam buku A Critical Handbook of Children's Literature. Lukens (1999: 9) menjelaskan bahwa pada dasarnya sastra anak tidak berbeda dengan sastra dewasa. Menurutnya, keduanya hanya berbeda dalam "tingkatan", tapi tidak dalam jenisnya. Oleh karenanya, sastra anak harus menyediakan kesenangan dan manfaat yang sama sebagaimana yang disediakan dalam sastra dewasa.

Terkait ending cerita dalam The Giver, penulis berpijak pada gagasan McDowell (1973: 51). Menurutnya, sastra anak mempunyai beberapa kriteria khusus yang membedakannya dari sastra dewasa. McDowell berpendapat bahwa sastra anak cenderung memiliki ending optimis daripada depresif. Akh- ir cerita yang bahagia atau happy ending penting dimunculkan dalam cerita anak karena mampu menginspirasi anak bersikap optimis menjalani hidupnya.

\section{e) Metode Penelitian}

Penelitian ini menggunakan pendekatan kualitatif karena tujuan penelitian ini menginterpretasikan sebuah karya sastra. Selain itu, data dalam penelitian ini juga tidak berupa angka-angka dan korpus yang diteliti akan dideskripsikan dalam bentuk narasi atau bahasa. Hal ini selaras dengan pernyataan Vanderstoep danJohnston (2009:7) bahwa dalam penelitian kualitatif seorang peneliti akan menghasilkandiskripsi naratif atau tekstual dari fenomena yang diteliti.

Sumber primer penelitian ini adalah novel dan film anak berjudul The Giver. Novelnya ditulis Lois Lowry, diterbitkan pada tahun 1993 di New York. Novel ini terdiri dari 23 chapter, 179 halaman. Sementara filmnya disutradarai Phillip Noyce dan ditayangkan tahun 2014. Data penelitian adalah data yang mengindikasikan dominasi (kekerasan simbolik) dan resistensinya terhadap dominasi tersebut. Data tersebut bisa berbentuk kata, frasa, klausa, kalimat, ataupun dialog.

Dalam proses pengumpulandata, peneliti melakukannya melaluibeberapa tahap. Pertama, peneliti membaca dan membaca ulang novel The Giver secara komperehensif untuk mendapatkan pemahaman mendalam mengenai isi novel tersebut. Kedua, penulis menonton dengan seksama film The Giver. Ketiga, penulis mengidentifikasi persamaan dan perbedaan yang ada dalam novel dan film tersebut. Keempat, penulis menginterpretasikan misidan ideologi pada per- 
samaan dan perbedaan yang ada dalam novel dan film tersebut sebagaimana yang menjadi tujuan penulis. Kelima, hasil interpretasi tersebut kemudian penulis tulisakan dalam bentuk narasi.

\section{B. Pembahasan}

Sebagaimana disebutkan sebelumnya, ekranisasi The Givertermasuk dalam alih wahana kritis yang tetap mempertahankan garis besar teks asli meskipun mengalami beberapa perubahan. Beberapa persamaan seperti tema, tokoh, dan latar bisa ditemukan dalam ekranisasi ini. Baik dalam novel maupun film sama-sama menyuarakan isu tentang dominasi. Latar dalam novel dan film ini sama, yakni dalam sebuah komunitas tempat mereka tinggal. Sementara dari segi tokoh, film ini menghadirkan tokoh-tokoh yang sama, yaitu Jonas, The Giver, Fiona, Asher, orang tua Jonas, Chief of Elder, The Commitee, Lily, dll. Sementara itu, ada beberapa perbedaan mendasar yang bisa ditemukan dalam novel dan film The Giver. Perbedaan-perbedaan ini mengusung makna dan ideologi tertentu. Analisis tentang makna ideologis perbedaan-perbedaan tersebutlah yang akan dikupas dalam bab ini. Berikut uraiannya:

\section{a) Memunculkan Modernisasi}

The Giver merupakan sebuah novel yang menceritakan sebuah komunitas yang hidup di bawah kontrol pemegang kekuasaan yang disebut dengan The Commitee. The Commitee menerapkan seperangkat aturan yang harus dipatuhi oleh komunitas tersebut. Dengan berlindung di balik "misi melindungi" komunitas tersebut dari kekacauan, The Commitee berhasil menerapkan dominasinya. Dominasi itu dilakukannya dengan sangat halus, sehingga komunitas tersebut tidak menyadari bahwa mereka sedang mengalami dominasi. Oleh Bourdieu, dominasi semacam ini diistilahkannya sebagai kekerasan simbolik. Kekerasan jenis ini termasuk yang paling sulit diatasi mengingat sifatnya yang sangat halus karena disampaikan melalui wacana. "Symbolic domination... is something you absorb like air, something you don't feel pressured by; it is everywhere and nowhere, and to escape from that is very difficult" (Bourdieu, dalam Bourdieu dan Eagleton 1992e: 115).

Dalam menyebarkan wacana, pihak dominan akanmenyebarkannya melalui permainan bahasa. Menurut Bourdieu (dalam Bourdieu dan Eagleton, 1992e: 111) bahasa merupakan media efektif untuk menyalurkan dominasi. Bourdieu melihat bahasa bukan hanya sebagai media komunikasi, tapi juga "an instrument of power and action". Untuk menyampaikan dominasinya, kaum dominan akan menggunakan bahasanya sebaik mungkin sehingga pihak terdominasi akan menyerap dan mematuhi apa yang mereka katakan. Mereka bahkan akan menyeleksi aksen, intonasi, bahkan diksi dalam upaya menyampaikan kekuasaannya.

Ketika wacana tersebut sudah berhasil diserap pihak terdominasi, selanjutnya wacana tersebut membutuhkan "seperangkat media" untuk mendukung wacana tersebut beroperasi. Dalam ranah praktis, media tersebut bisa berupa alat berbentuk fisik. Dalam novel The Giver bisa ditemukan seperangkat alat yang bisa diidentifikasi sebagai media pendukung dominasi itu bekerja. Misalnya, pil yang harus ditelan untuk menekan hasrat seksual atau adanya sistem pengawasan -meskipun man- 
ual - ketika Jonas akan memasuki ruangan The Giver. Uniknya, ketika dialihwahanakan menjadi film, seperangkat alat pendukung dominasi tersebut mengalami perubahan. Alat-alat tersebut diubah menjadi lebih modern.

Proses ekranisasi The Giver dilakukan dalam rentang waktu lebih dari dua puluh tahun.Dalam rentang waktu tersebut, dunia banyak mengalami perkembangan yang ditandai dengan barmacam temuan di bidang teknologi.Adanya perkembangan teknologi menandai suatu peradaban bergerak menuju modernitas. Di dunia modern seperti saat ini, dua dekade merupakan rentang waktu yang lama bagi dunia teknologi untuk menemukan kemutakhiran-kemutakhirannya.Hal ini juga disadari oleh sutradara dan direpresentasikan dalam ekranisasi The Giver.Berbeda dengan novelnya, film The Giver memasukkan unsur-unsur teknologi modern yang digunakan oleh komunitas yang menutup diri terhadap perbedaan-perbedaan dunia luar tersebut.

Ada beberapa scene dalam film yang memasukkan teknologi baru yang tidak bisa ditemukan dalam novel. Dalam novel, ketika Jonas akan melarikan diri menuju Elsewhere dengan membawa Gabriel, ia melarikan diri menggunakan sepeda. Ia mengayuh sepeda sekuat tenaga hingga sampai di Elsewhere di tengah kejaran The Commitee, karena dalam peraturannya The Receiver atau penerima memori tidak boleh melarikan diri.Di tengah situasi yang tegang dan penuh tekanan seperti itu, Jonasharus terus mengayuh sepedanya bahkan ketika ia kelelahan dan kelaparan karena keterbatasan bekal yang dibawanya.
Thrid, he had stolen his father's bicycle. He had hesitated for a moment, standing beside the bikeport in the darkness, not wanting anything of his father's and uncertain, as well, whether he could comfortably ride the larger bike when he was accustomed to his own.

But it was necessary because it had the child seat attached into the back. And he had taken Gabriel, too.

(TheGiver novel, 1993: 166).

Dalam film, proses pelarian ini dilakukan Jonas menggunakan sepeda motor. Perubahan antara sepeda kayuh dengan sepeda motor merupakan salah satu wujud upayasutradara memasukkan unsur modernitas. Hal ini bisa dibaca sebagai upaya sutradara untuk menyesuaikan perkembangan zaman agar lebih bisa diterima penonton. Selain itu, perubahan tersebut juga bisa dimaknai sebagai usaha merasionalisasikan upaya resistensi. Untuk bisa sampai Elsewhere, Jonas harus menempuh perjalanan yang sangat jauh dan belum pernah dikunjunginya. Tambah lagi, perjalanan itu dilakukan di tengah kejaran The Commitee dan bekal makanan yang terbatas. Dengan sepeda motor, perjuangan itu akan lebih mudah dan menjadi lebih masuk akal ketika Jonas akhirnya bisa sampai di tempat tujuannya.

Perbedaan juga bisa ditemukan dalam bentuk aturan yang mengharuskan komunitas menekan hasrat seksualnya. Aturan ini diberlakukan untuk mengeliminasi ketertarikan terhadap lawan jenis dan menekan potensi terjadinya praktik hubungan seksual di antara masyarakat. Dalam komunitas tersebut, 
semua aktivitas masyarakatnya berada di bawah kontrol The Commitee, termasuk perihal angka kelahiran. The Commitee membuat aturan bahwa ada orang khusus yang ditugaskan sebagai birthmother. Merekalah yang akan melahirkan anak dan anak tersebut kemudian diasuh oleh masyarakat terpilih dalam komunitas tersebut. Karena hal ini, dalam komunitas tersebut tidak mengenal "makna keluarga" yang sebenarnya.

Dalam novel, upaya penekanan hasrat seksual dilakukan masyarakat dengan cara menelan obat berbentuk pil. Sementara itu, dalam film penekanan hasrat seksual tersebut dilakukan dengan cara menekankantangan pada sebuah mesin suntik. Perbedaan dari obat yang harus telan dengandisuntikan merupakan representasi perkembangan teknologi medis dari yang kuno menjadi modern.

Modernisasi lainnya juga dapat ditemukan pada adanyamesin deteksi diri ketika Jonas memasuki Annex Room, ruangan di mana ia mendapatkan pelatihan transfer memori dari The Giver. Dalam novel, cara itu dilakukan dengan manual, yakni ada suara orang dari dalamyang menyambut dan mempersilakannya masuk. Ketika tahu Jonas datang, pintu ruangan tersebut akan terbuka. Namun, dalam film hal itu dilakukan dengan cara berbeda yakni melaluiscan kornea mata. Ketika akan memasuki Annex Room, Jonas harus melakukan scan kornea yang disediakan di pintu masuk ruangan. Hal ini juga menunjukkan adanya pergeseran cara dari yang manual menjadi modern.

Selain itu, modernisasi juga ditunjukkan dengan adanya drone sebagai mesin pengontrol komunitas. Dalam novel, tidak ada sistem pengawasan sep- erti ini.Jika dilihat lebih jauh, drone merupakan sebuah teknologi mutakhir yang salah satu fungsinya bisa digunakan sebagai alat pengawasan ataupun mesin rekam. Drone bisa merekam semua aktivitas manusia dari jarak jauh maupun dekat dan bisa beroperasi tanpa harus melibatkan manusia secara langsung. Dalam hal ini, drone berfungsi sebagai pengawas ataupanopticon yang digunakan untuk mengawasi seluruh gerak-gerik dan aktivitas masyarakat dalam The Giver.

Dengan demikian, modernitas selalu menyisakan hal-hal paradoksal, sebagaimana direpresentasikan dalam film ini. Pada satu sisi, teknologi bisa membantu manusia melepaskan diri dari praktik dominasi, sebagaimana sepeda motor bisa membantu Jonas melarikan diri dengan lebih mudah dan cepat mencapai Elsewhere. Di sisi lain, teknologi juga bisa menjadi bumerang yang justru mengancam manusia terhadap praktik dominasi, sebagaimana direpresentasikan melalui dronedalam film ini.Berkaca pada bagaimana drone difungsikan dalam komunitas tersebut, dapat dilihat bagaimana modernitas semakin membuka peluang berlangsungnya kelanggengan dominasi.

Hal ini senada dengan apa yang disampaikan Frank Herbert (19201986), seorang penulis Amerika bergenre science fictionyang mengatakan bahwa pada satu sisi teknologi berfungsi mempermudah manusia, tapi di sisi lain justru sebaliknya. Hal-hal yang saling tarik-menarik seperti ini akan selalu dihadapi masyarakat modern. "Technology is both a tool for helping humans and for destroying them. This is the paradox of our times which we're compelled to face."Sebagai sebuah film yang dibuat pada era modern, film The Giver memo- 
tret bagaimana hubungan tarik-menarik antara modernitas dengan praktik dominasi.

\section{b) PerubahanUsiaTokoh}

Selain memasukkan unsur modernitas dalam filmnya, perubahan signifikan dalam ekranisasi The Giver juga bisa ditemukan pada usia tokoh-tokoh yang ada di dalamnya. Dalam novel, tokoh Jonas, Fiona, dan Asher adalah anak-anak berumur 11 tahun.

"When I was an Eleven," his fa-
ther said now, "as you are, Jo-
nas, I was very impatient, wait-
ing for the Ceremony of Twelve.

(The Giver novel, 1993: 13)

Kutipan di atas diucapkan ayah Jonas yangbercerita tentang perasaannya ketika berusia 11 tahun, sama seperti Jonas saat itu. Sebagaimana Jonas, dulu ayahnya juga tidak sabar menunggu berlangsungnya Ceremony of Twelve. Dalam upacara tersebut, setiap anggota komunitas akan meninggalkan masa anak-anaknya dan mendapat tugas yang dipilihkan The Commitee untuk mereka. Melalui kutipan tersebut, dapat diketahui bahwa tokoh Jonas pada waktu itu berumur 11 tahun atau hampir memasuki usia 12 tahun. Tidak hanya Jonas, tokoh lain yang merupakan teman sepermainan sekaligus teman sekolah Jonas yaitu Fiona dan Asher juga berusia sama dengannya.

Sementara itu, dalam film ketiga tokoh ini dibuat menjadi remaja berumur 16 tahun. Artinya, tokoh-tokoh ini tidak lagi merupakan tokoh anak-anak, melainkan remaja. Meskipun tidak ada patokan pasti tentang fase pertumbuhan dan perkembangan manusia, Erik H. Erikson, seorang penggagas konsep perkembangan psikososial manusia (dalam McLeod, 2017)mengkategorikan perkembangan manusia dalam delapan tahap. Yaitu, masa bayi pada usia 0-1,5 tahun, tahap kanak-kanak awal antara 1,5-3 tahun, tahap usia bermain yakni 3-5 tahun. Masa usia sekolah (masa kanak-kanak akhir) antara 5-12 tahun. Masa remaja yaitu 12-18 tahun. Masa dewasa awal 18-40 tahun, masa dewasa middle antara 40-65 tahun, dan masa dewasa akhir 65 tahun hingga meninggal. Beranjak dari pembagian usia menurut Erikson tersebut, dapat dikatakan bahwa kategori anak adalah yang masuk pada usia 3-12 tahun, sedangkan yang dikategorikan remaja adalah yang berusia 1218 tahun.

Jika dilihat lebih jauh, perubahan umurpara tokoh ternyataturut memengaruhi banyak aspek dalam film The Giver. Salah satunya adalah terjadinya pergeseran sasaran penonton. Novel The Giver merupakan sastra anak yang artinya mempunyai sasaran pembaca anak. Jika dalam novel sasaran pembacanya merupakan anak-anak, dalam film sasaran penontonnya "dinaikkan" menjadi anak muda atau remaja. Ketika tokoh dalam film ini dibuat menjadi 16 tahun, mereka tidak lagi menjadi anak-anak, tapi remaja.

Lebih jauh lagi, "peremajaan" tokoh dalam ekranisasi The Giverjuga bisa dibaca sebagai upaya pergeseran ideologi perihal agen pengubah struktur masyarakat. Jika dalam novel anak diyakini mempunyai kekuatan sebagai agen pengubah suatu tatanan masyarakat, dalam filmnya justru tidak mempunyai keyakinan yang sama.Dalam film, agen perubahan itu justri disematkan pada anak muda atau remaja. Anak mudalah yang mempunyai pernanan besar dalam mengubah suatu tatanan masyarakat. 
William A. White (dalam Crisp, 2009) seorang jurnalis dan penulis yang namanya diabadikan sebagai sebuah nama penghargaan untuk buku anak, yakni William Allen White Children's Book Award mengamini pentingnya peranan pemuda dalam mengubah dunia. Menurutnya, memang pemudalah yang harus gigih melakukan perubahan. Pemuda tidak selayaknya menjadi subjek pasif yang menerima perintah atau aturan para tetua jika ingin menciptakan perubahan dunia. Ujarnya, "Youth should be radical. Youth should demand change in the world. Youth should not accept the old order if the world is to move on."

Jika dianalisis lebih jauh, perubahan usia tokoh anak menjadi remaja dalam ekranisasi The Giver juga secara tidak langsung telah mengubah pesan yang ingin disampaikan antara penulis dan sutradara.Melalui film ini, sutradara berupaya menyuarakan bahwa di tangan anak mudalah perubahan-perubahan lebih mudah diciptakan. Hal ini bisa dimaknai sebagai upaya sutradara melihat bagaimana konvensi memandang anakanak yang "cenderung tidak didengar". Pada umumnya anak-anak dianggap sebagai makhluk "lunak" yang justru membutuhkan perlindungan. Mempercayakan perubahan struktur pada anak-anak justru terlihat sedikit utopis. Sebaliknya, dengan mempertimbangkan pengalaman, pengetahuan, serta kelincahan fisik yang dimiliki, anak muda cenderung lebih bisa dipercaya dalam melakukan perubahan tersebut.

\section{c) Perubahan Watak Tokoh}

Selain adanya perubahan usia pada tokoh, ketiga tokoh yaitu Jonas, Fiona, dan Asher juga mengalami perkembangan dalam hal perwatakan.
Perubahan karakter di antara ketiganya bahkan terlihat sangat jelas dalam ekranisasi The Giver. Perubahan ini juga mempunyai makna tersendiri jika dicermati. Salah satu perubahan watak yang paling signifikanadapada tokoh Fiona. Dalam novel, tokoh Fiona tidak lagi banyak diceritakan setelah Jonas mendapatkan tugas sebagai penerima memori atau The Receiver sementara Fiona menjadi perawat. Kisah lebih banyak bercerita seputar usaha Jonas mengembalikan memori ke Elsewhere sehingga masyarakat dalam komunitas tersebut bisa hidup normal.

Hal berbeda ditunjukkan dalam film. Fiona justru mempunyai peran besar dalam membantu Jonas melarikan diri bersama Gabriel menuju Elsewhere. Gabriel adalah seorang bayi yang "dianggap berbeda" oleh The Commitee. Sebagaimana aturan yang diterapkan dalam komunitas tersebut, manusia yang dianggapberbeda harus segera mendapatkan release atau disuntik mati. Untuk menyelamatkan Gabriel dari prosesi release, Jonas memutuskan untuk membawanya.

Setelah Jonas mengetahui fakta sesungguhnya mengenai memori yang disimpan dalam diri The Giver, Jonas melakukan perlawanan. Ia ingin masyarakat bisa hidup normal, bisa merasakan sedih dan senang sebagaimana yang bisa ia rasakan. Sementara itu, Jonas tahu bahwa cara satu-satunya adalah dengan mengembalikan semua memori itu kepada masyarakat. Cara yang harus ditempuh Jonas adalah dengan melarikan dirimenuju Elsewhere.Dalam novel, kisah perjuangan Jonas mengembalikan memori menuju Elsewheredilakukannya sendiri. Cerita lebih berkutat pada bagaimana ia dengan menggendong Gabriel melarikan diri menggunakan 
sepeda menuju Elsewehere, bersusah payah dengan menggunakan sisa-sisa tenaga dan bekal yang dibawanya. Ia juga menggunakan memori yang diberikan The Giver sebagai bekal pengalaman yang ia gunakan selama perjalanan. Proses pelarian tersebut dilakukannya tanpa bantuan siapapun.

That night, Jonas was forced to flee. He left the dwelling shortly after the sky became dark and the community still. It was terribly dangerous because some of the work crews were still about, but he moved stealthily and silently, staying in the shadows, making his way past the darkened dwellings and the empty Central Pla$z a$, toward the river. Beyond the Plaza he could see the House of the Old, with the Annex behind it, outlined against the night sky.

But he could not stop there. There was no time. Every minute counted now, and every minute must take him farther from the community.

(The Giver novel, 1993:163).

Hal berbeda ditunjukkan dalam film. Dalam film, tokoh Fiona dan Asher banyak dilibatkan dalam proses pelarian Jonas. Fiona yang memahami bahwa komunitas tersebut telah mengalami kebohongan atas kebenaran, membantu proses pelarian Jonas. Ia yang berprofesi sebagai perawat bayi membantu Jonas mengecoh orang-orang yang ditugaskan untuk menangkap Jonas. Ketika akan mengambil Gabril di rumah perawatan bayi, Fiona berlari seolah-olah membawa Gabriel, padahal Gabriel telah diba- wa lari Jonas ke arah yang berlawanan.

Simone de Beauvoir dalam Second Sex (1987) mengatakan bahwaperempuan selalu ditempatkan sebagai kelamin kedua oleh masyarakat luas. Kehadiran perempuan tidak diakui secara setara, melainkan berada di bawah laki-laki. Perempuan dianggap sebagai yang liyan atau the other. Perempuan selalu distereotipkan sebagai sosok yang lemah, tidak berani bersuara, dan tidak mandiri. Sementara itu, kaum laki-laki memposisikan dirinya sebagai the self atau dirinya sendiri.Beranjak dari argumen Bouvoir tersebut, maka dapat dilihat bahwa tindakan Fiona membantu Jonas merupakan sebuah upaya sutradara membalik stereotip bahwa perempuan selalu dipandang lemah dan bergantung pada laki-laki. Dalam film ini, sutradara memberi ruang terhadap perempuan untuk menunjukkan eksistensi dan peranannya. Meskipun Fiona tahu ia akan menerima hukuman dari The Commitee jika tertangkap, ia tetap membantu Jonas.

Selain itu, dalam film tokoh Fiona juga digambarkan sebagai sosok perempuan yang berani bersuara. Hal itu bisa dilihat dalam dialog antara ibu Jonas dan Fiona berikut ini:

Fiona, I've taken care of everything. We've arranged for your Release. There'll be a nice ceremony.Now, you get some rest.

(Ibu Jonas, dalam film The Giver, 2014)

I felt things. I know that there's. Something more. Something missing from our lives. No, not missing. Something that has been stolen from me and from 
you. I don't know what it is exactly, but Jonas does.I have felt things, and they were warm, and they were nice. They were beautiful.They were beautiful.

(Fiona, dalam film The Giver, 2014)

Dialog di atas terjadi antara Fiona dan Ibu Jonas yang bertugas menyiapkan upacara suntik mati Fiona. Ketika akan disuntik mati sebagai hukuman yang harus diterima karena telah membantu Jonas melarikan diri, dalam keadaan tegang dan tertekan Fiona masih berani mengatakan apa yang ia ketahui dan rasakan. Ia berkata kepada Ibu Jonas bahwa ia mempunyai emosi dan bisa merasakan sesuatu yang berbeda yang tidak bisa dilakukan orang lain di komunitasnya. Ia mengatakan bahwa perasaan yang dirasakannya itu sangat nyaman, meski ia tidak bisa menjalaskan perasaan seperti apa yang sebenarnya ia alami. Pada dasarnya perasaan yang dirasakan Fiona tersebut adalah perasaan cinta atau kasih sayang, perasaan yang tidak dimiliki komunitas tersebut karena telah dieliminasi bersama dengan memori yang lain. Fiona mengenalinya karena diajarkan oleh Jonas. Namun, karena sebelumnya Fiona tidak pernah mengenal konsep cinta dan kasih sayang, maka ia tidak dapat mengidentifikasi penamaan atas perasaan tersebut.

Tindakan Fiona tersebut juga sekali lagi membalikkan stereotip perempuan yang hanya dianggap sebagai objek. Keberanian Fiona menunjukkan sikapnya sebagai subjek yang bebas dan berani mengartikulasikan dirinya. Hal ini senada dengan yang sampaikan Beauvoir (dalam Arivia, 2013) mengenai konsep manusia sebagai subjek, yaitu ketika manusia itu memiliki kebebasan atas dirinya sendiri. "Menjadi manusia bebas adalah menjadi subjek," tulisnya. Artinya, ketika menjadi objek, perempuan kehilangan kebebasannya untuk bebas berpikir. Ketika Fiona berani mengatakan apa yang dirasakan dan diketahui, ia telah merepresentasikan sosok perempuan sebagai subjek bebas. Di sini Fiona berhasil merepresentasikan dirinya sebagai simbol perempuanbebas yang berani melawan dominasi.

Sebagaimana Fiona, penokohan Asher juga mengalami perubahan. Jika di novel Asher mempunyai karakterisasi yang flat atau statis, di film justru sebaliknya. Dalam film, Asher ditunjukkan mempunyai karakter dinamis, yakni mengalami perubahan di awal dan di akhir cerita. Menurut Lukens(1999: 86-88), ada dua jenis penokohan dalam karya sastra, yaitu flat dan round characters.Flat karakter bersifat statis, meskipun ia mempunyai peranan besar dalam cerita, perwatakannya tidak mengalami perubahan secara signifikan. Sebaliknya, round character mempunyai perwatakan dinamis karena selama berjalannya cerita ia mengalami perubahan yang signifikan. Oleh karenanya, tindakan dan reaksinya seringkali tidak dapat ditebak dan mengejutkan pembaca atau penonton. Pembaca mengetahui bagaimana perwatakan round character tidak hanya melalui tindakannya, tapi juga melalui pembicaraan dan pendapat orang lain tentang dirinya. Bahkan, bisa juga datang dari deskripsi penulisnya.

Di dalam ekranisasi ini, pada mulanya Asher digambarkan sebagai sosok teman baik atau teman sejati bagi Jonas dan Fiona. Layaknya pertemanan anak-anak pada umumnya, ketidanya kerap menghabiskan waktu bermain bersama. Perubahan mulai ditunjukkan 
melalui konflik-konflik khas remaja seperti halnya kecemburuan atau cinta segi tiga. Asher seringkali cemburu pada Jonas yang terlihat dekat dengan Fiona. Pada klimaksnya, Asher bahkan menjadi tokoh antagonis yang ditunjukkan melalui sikapnya ketika melaporkan proses pelarian Jonas dari komunitas tersebut. Ketika melarikan diri di tengah malam, Asher memergoki pelarian Jonas tersebut dan mencoba menghalangi Jonas. Pada saat itu keduanya bahkan sempat berkelahi. Jonas yang yakin dengan keputusannya akhirnya tetap pergi meninggalkan komunitasnya. Mengetahui hal itu, akhirnya Asher melaporkan pelarian Jonas pada The Commitee dan Pimpinan The Commitee atau Chief of Elder memerintahkan Asher yang bertugas sebagai pilot untuk menangkapnya.

Jonas was chosen for the most important position in our community. He was asked if he was strong enough. It turned out he was not. Instead, he is a rebel. He must be stopped. By you. When you find him, take him.

(Chief of Elder, dalam film The Giver, 2014)

Kutipan di atas merupakan perintah Chief of Elder kepada Asher untuk menangkap Jonas. Meskipun pada mulanya Asher menjadi tokoh antagonis yang menentang pelarian diri Jonas dan melaporkannya pada The Commitee, di akhir Asher justru berubah dan mendukung pelarian Jonas. Pada mulanya ia menangkap Jonas, tapi kemudian melepaskannya ke sungai. Hal itu dilakukannya untuk mengecoh The Commitee solah-olah Jonas telah tenggelam di sungai, tapi pada dasarnya Asher tahu bahwa Jonas selamat. Sementara itu, ia mengatakan kepada The Commitee bah- wa Jonas telah meninggal.

Dalam hal ini, bisa dilihat bagaimana perubahan watak antara Asher dan Fiona dalam film ini dihadirkan secara seimbang.Hal ini bisa dimaknai sebagai misi sutradara untuk menegaskan bahwa perjuangan mengubah suatu tatanan sejatinya tidak hanya bisa dilakukan laki-laki, tapi juga perempuan. Asher mempunyai peranan besar dalam membantu proses pelarian Jonas, sebagaimana yang dilakukan Fiona. Tanpa bantuan Asher, besar kemungkinan Jonas tidak akan selamat dari kejaran The Commitee. Sedangkan tanpa bantuan Fiona, besar kemungkinan Jonas akan gagal menyelamatkan dan membawa lari Gabriel untuk bisa ikut serta dengannya.

Selain itu, perubahan yang dilakukan sutradara tehadap penokohan Fiona dan Asher yang banyak berkontribusi pada perjuangan Jonas juga memperkuat penokohan Jonas sebagai tokoh protagonis "yang bisa dipercaya". Jonas tidak dihadirkan sebagai sosok sempurna, melainkan sebagai manusia biasa yang juga membutuhkan peran dan bantuan orang lain dalam kehidupannya. Jonas adalah hero dalam cerita ini, tapi kepahlawanannya itu masih bersifat logis sebagai seorang manusia yang punya kelemahan dan membutuhkan bantuan orang lain dalam melakukan tindakan kepahlawanannya. Sebagaimana yang dikatakan Singh (2006) tentang konsep tokoh protagonis, menurutnya tokoh utama yang dihadirkan sebagai seorang pahlawan cerita dapat dikatakan berhasil jika mampu menunjukkan individu yang kompleks dalam dirinyayang mempunyai watak positif dan negatif. Para tokoh ini akan menjadi role model jika mampu menaklukkan kelemahan dan watak negatifnya sendiri. Sen- 
ada dengan Singh, Lukens (1999) juga menjelaskan bahwatokoh ideal perlu memenuhi syarat untuk bisa dipercaya dan untuk bisa dipercaya seorang tokoh perlu memiliki banyak dimensi.

Dengan demikian, pada dasarnya novel ini berhasil memotret karakterisasi ideal dalam diri para tokoh seperti The Giver, Jonas, Fiona, dan Asher yang mempunyai dimensi baik dan buruk.Di dalam film, melalui perubahan karakterisasi pada Fiona dan Asher, karakterisasi ideal pada Jonas sebagai pahlawan yang berhasil melakukan perlawanan dan mengubah tatanan masyarakat komunitasnya semakin kuat terepresentasikan.

\section{d) Perubahan Ending}

Menurut Lukens (1999: 122123), ada dua jenis endingatau penyelesaian dalam sebuah cerita, yakni terbuka atau menggantung dan tertutup atau pasti. Sebuah cerita mempunyai penyelesaian terbuka ketika pembaca diberi keleluasaan untuk menentukan bagaimana akhir dari sebuah cerita. "The reader is left to draw their own conclusion about the final plot conclusion." Sementara itu, sebuah cerita dikatakan mempunyai penyelesaian tertutup ketika cerita tersebut dengan jelas menunjukkan bagaimana akhir ceritanya, apakah berakhir bahagia atau justru sebaliknya. Penyelesaian ini disebut tertutup karena penulislah yang memberikan atau menentukannya. "The reader is assured that all is well and they get the good conclusion of the story."

Dalam ekranisasi ini, perbedaan signifikan juga ditunjukkan melalui penyelesaianceritanya. Novel The Giver mempunyai penyelesaianterbuka. Cerita selesai ketika Jonasbangun dari ketidaksadaran setelah kehabisan tena- ga menuju Elsewhere. Ia melihat sebuah rumah yang di dalamnya ada cahaya warna-warni, ia juga mendengar musik dari dalam rumah itu. Dari tempatnya berdiri, di kejauhan ia juga selolah melihat dan mendengar hal yang sama. Hal ini menyiratkan bahwa ia seolah sudah sampai di tempat tujuannya dan berhasil mengembalikan memori kepada masyarakatnya. Namun, penulis novel kembali menuliskan bahwa bisa jadi itu hanyalah gaung yang merupakan ilusi Jonas yang hilang kesadaran karena kelelahan. Penulis memberikan keleluasaan pada pembaca, apakah Jonas sebenarnya berhasil mencapai Elsewhere dan mengembalikan memori itu atau justru sebaliknya. Hal itu bisa dilihat dalam kutipan berikut ini, yang merupakan kalimat penutup novel tersebut:

Suddenly he was aware with certainty and joy that below, ahead, they were waiting for him; and that they were waiting, too, for the baby. For the first time, he heard something that he knew to be music. He heard people singing. Behind him, across vast distances of space and time, from the place he had left, he thought he heard music too. But perhaps it was only an echo.

(The Giver novel, 1993)

Sementara itu, dalam film penyelesaiannya ditunjukkan sebaliknya. Film ini menghadirkan penyelesaian tertutup, yakni happy ending.Di akhir cerita, Jonas berhasil mencapai Elsewhere, sehingga semua memori berhasil dikembalikan kepada komunitas. Ketika memori itu dikembalikan, seketika masyarakat seolah tersentak dan sadar bahwa mereka bisa merasakan perasaan yang berbeda. Mereka mempunyai emo- 
si yang selama ini dihilangkan dalam komunitas tersebut. Ayah Jonas yang saat itu bertugas melakukan release atau menyuntik mati Fiona sebagai hukuman karena telah membantu Jonas melarikan diri, tiba-tiba seolah tersadarkan dan kemudian menghentikan proses releasetersebut. Demikian halnya dengan semua masyarakat yang ada dalam komunitas tersebut. Mereka seolah tersentak dan tersadarkan dari kebohongan pola kehidupan mereka selama ini.

I wish I had been there when the memories returned. They were the truth. The Elders and their rules were the lie. So I do not apologize. I knew Fiona was safe that I'd see her again and that I held the future there in my arms. The Giver had led us here to this house. It was real. From far behind me, from the place I had left, I thought I heard music, too. Perhaps it was only an echo, but it was enough. It would lead us all home.

\section{(The Giver movie, 2014)}

Jika dicermati, ada perbedaan signifikan yang bisa dilihat dalam dua kutipan di atas berkaitan dengan penyelesaian cerita dan maknanya. Dalam novel, penyelesaian diakhiri dengan kalimat but perhaps it was only an echo. Sementara di film, setelah kalimat yang sama diucapkan, Jonas melanjutkannya dengan but it was enough. It would lead us all home. Ia juga tahu bahwa The Elders dan semua aturan yang mereka buat adalah kebohongan. Jonas mempertegas keberhasilannya dengan keyakinan bahwa ia telah berhasil, Fiona pasti selamat, dan ia akan bertemu lagi dengan Fiona di kemudian hari. Ia akan mempunyai masa depan sebagaimana mestinya.
Dari kutipan tersebut, didukung dengan visualisasi filmnya, menunjukkan Jonas berhasil mengembalikan memori kepada komunitasnya. Setelah Jonas sampai di Elsewhere, film itu menghadirkan potret keberagaman seperti suku, budaya, dan agama. Selain itu, juga dimunculkan potret manusia berekspresi sedih, menangis, tertawa, bahagia, juga jatuh cinta. Ada juga potert prosesi kelahiran, pernikahan, kematian, dan peperangan. Hal ini bisa dimaknai sebagai simbol keberhasilan Jonas mengembalikan memori kesedihan dan kebahagiaan yang sebenarnya kepada komunitasnya. Visualisasi tersebut menggambarkan bagaimana bentuk kehidupan seharusnya berjalan. Kehidupan yang alami adalah yang manusianya mengenal keberagaman dan bisa hidup berdampingan dengan perbedaan-perbedaan itu. Manusia juga idealnya mempunyai pilihan atas hidupnya sendiri, serta emosi-emosi yang mengikutinya.

Berkaitan dengan perubahan penyelesaian dari terbuka menjadi tertutup (happyending, McDowell (1973: 51) mempunyai argumen terkait hal ini. Menurutnya,sastra anak mempunyai beberapa kriteria khusus yang membedakannya dari sastra dewasa. Menurutnya, sastra anak cenderung memiliki penyelesaianoptimis daripada depresif. Happy ending penting dimunculkan dalam cerita anak karena mampu menginspirasi anak bersikap optimis menjalani hidupnya. Happy ending diharapkan bisa membantu anak-anak menyiapkan kehidupannya setelah melewati kepahitan dan memberinya sedikit harapan untuk melanjutkan hidupnya.

Children's books are generally shorter; they tend to favor an active rather than a passive treat- 
ment, with dialogue and incident rather than description and introspection; child protagonists are the rule; conventions are much used; the story develops within a clear-cut moral schematism which much adult fiction ignores; children's books tend to be optimistic rather than depressive; language is child-oriented; plots are of a distinctive order, probability is often disregarded; and one could go on endlessly talking of magic, and fantasy, and simplicity, and adventure. McDowell (1973: 51)

Sementara itu, Purbani (2009: 43) berpendapat bahwa akhir sebuah cerita dianggap penting karena bagian iniakan menggiring pembaca pada kesimpulan cerita. Penyelesaian tertutup membawa pembaca mendapatkan kesimpulan cerita sesuai dengan pilihanpenulisnya. Menurutnya, justru di sinilah biasanya ideologi beroperasi secara efektif. Dengan demikian, bagaimana happy ending yang dipilih sutradara dalam film ini juga merepresentasikan ideologi atau misi tersendiri. Jika McDowell menganggap happy ending berpotensi menanamkan sisi optimisme anak terhadap kepahitan hidup, maka hal itu juga berlaku pada film The Giver. Happy ending dalam film ini bisa dimaknai sebagai penegasan terhadap potensi keberhasilan dalam melakukanresistensi.Bagaimana sutradara memilih happy ending menunjukkan sisi optimisme yang ingin dibangun dalam melawan dominasi itu sendiri sehingga perubahanpun mudah dicapai.

Hal ini didukung dengan pendapat Bourdieu (dalam Schubert, 2008: 196), bahwasannyadominasi merupakan sebuah konstruksi, oleh karenanya sangat memungkinkan dilakukan
resistensi.Bourdieu mengistilahkannya dengan heterodox.Menurutnya,heterodoxsangat bisa diciptakan karena pada dasarnya aturan-aturan dalam sebuah tatanan masyarakat secara sosial dan sejarah merupakan sebuah konstruksi, sehingga selalu ada kesempatan untuk mengubah kondisi tersebut. Artinya, bisa dikatakan bahwa pemilihan happy ending dalam film ini merupakan bagian dari visi sutradara untuk menanamkan sikap optimis kepada pembaca muda dalam mengubah tatanan masyarakat.

\section{Kesimpulan}

Ekranisasi The Giver membuktikan bahwa sebuah karya adaptasi atau alih wahana tidak bisa dilihat sebagai sebuah karya turunan. Keduanya, baik novel maupun film mempunyai keunikannya masing-masing dengan visi dan ideologi berbeda yang diusungnya. Sebagaimana ditunjukkan dalam film The Giver yang memasukkan unsur modernisasi di dalamnya, menunjukkan bahwa dunia yang kian modern nyatanya tidak lantas menghapuskan praktik dominasi. Modernitas menyisakan hubungan yang saling tarik-menarik terkait praktik dominasi. Pada satu sisi modernitas berfungsi mereduksi praktik dominasi, tapi di sisi lain justru mendukung dan melanggengkan praktik dominasi tersebut. Namun demikian, sebagaimana direpresentasikan dalam ekranisasi The Giver, seberapapun kerasanya praktik dominasi beroperasi, selalu ada peluang pihak terdominasi untuk melakukan perlawanan. Perlawanan tersebut penting dilakukan untukmengubah struktur yang telah usang dan menciptakan tatanan baru lebih baik. Sementara itu, perlawanan itu menjadi efektif ketika dilakukan oleh anak muda ketimbang anak-anak. Tidak hanya oleh pemuda laki-laki, tapi perla- 
wanan atas dominasi juga sangat potensialdilakukan oleh remaja perempuan.

\section{Daftar Pustaka}

BukuArivia, Gadis. 2013. "Filsafat, Hasrat, Seks dan Simone de Beauvoir" (dalam buku Subjek yang Terkekang). Jakarta: Komunitas Salihara.

Bourdieu, Pierre. 1991. Language and Symbolic Power. Cambridge: Polity.

1989. Social Space and Symbolic Power. Sociological Theory 7, 14-25.

Bourdieu, Pierre and T. Eagleton. 1992. "In Conversation: Doxa and Common Life". New Life Review 191, 111-112.

Bourdieu, Pierre and Jean-Claude Passeron. 1990. Reproduction in Education, Society, and Culture. London: Sage Publications.

Crisp, Tom. 2009. The Book of Bill: Choice Words Memorable Men. Kansas City Andrew McMeel Publishing LLC.

Damono, Sapardi Djoko. 2014. Alih Wahana. Depok: Editum. Edisi revisi ke-2.

Grenfell, Michael. 2008. Pierre Bourdieu Key Concept. Stocksfield: Acumen Publishing Limited.

De Beauvoir, Simone. 1987. The Second Sex. Hardmondsworth: Penguin Books.

Erikson, E. H. 1950. Childhood and society. New York: Norton.

Haryatmoko. 2016. Membongkar Rezim
Kepastian. Yogyakarta: Kanisius.

Hunt, Peter (Ed.), 1999. Understanding Children's Literature. London: Routledge.

Lowry, Lois. 1993. The Giver. New York: Dell Laurel-Leaf.

Lukens, Rebecca J. 1999. A Critical Handbook of Children's Literature (Sixth Edition). New York: Longman.

McDowell, Myles. 1999. "Fiction for Children and Adults: Some Essential Differences, Children's Literature in Education" in Hunt, Peter (Ed.) Understanding Children's Literature. London: Routledge.

Moleong, L. 2010. Metodologi Penelitian Kualitatif (Revised Ed.). Bandung: PT. Remaja Rosdakarya.

Singh, Manjari. 2006. "Exploring the Function and Heroes and Heroines in Children's Literature From Around the World". New York: Eric Digest.

Vanderstoep, Scott W., dan Johnston, Deidre D. 2009. Research Methods for Everyday Life. United Kingdom: Jossey Bass Wiley.

\section{Disertasi}

Purbani, Widiastuti. 2009. Ideologi Anak Ideal Dalam Lima Fiksi Unggulan Indonesia Akhir Masa Orde Baru. (Disertasi). Universitas Indonesia. Depok. 


\section{Jurnal}

George, Marshall. "Comparing Middle Grade Teachers' and Middle Grade Students' Reader Responses to Newbery Award Winners: A True Teacher's Lounge Story and the Question It Raised". (Electronic Journal). ALAN Review Volume 36, Number 1 (Fall, 2008). Diakses pada 1 Mei 2017, dalam alamat http://scholar. lib.vt.edu/ejournals/ALAN/ v36n1/george.html.

Gross, Mellisa. "'The Giver' and Shade's Children: Future Views of Child Abandonment and Murder". Children's Literature in Education v30 n2 (Juni, 1999) halaman 103-17.

Johnson, Angela Beumer., Jeffery W. Kleismit., and Antje J. Williams. "Grief, Thought, \& Appreciation: Re-examining Our Values Amid Terrorism through 'The Giver'". (Electronic Journal). ALAN Review, v29 n3 p15-19 Spr-Sum (Spring/Summer, 2002). Diakses pada 1 Mei 2017, dalam alamat https:// scholar.lib.vt.edu/ejournals/ ALAN/v29n3/johnson.html.

Susan G, Lea. "Seeing Beyond Sameness: Using 'The Giver' to Challenge Colorblind Ideology". Children's Literature in Education v37 n1 (Maret, 2006) halaman 51-67.

\section{Internet:}

Gross, Jessica. 1 Agustus 2014. "Lois Lowry on Giving Up 'The Giver' to Hollywood". Diakses pada 1 Mei 2017, dalam alamat https://www.nytimes. com/2014/08/03/magazine/lois-lowry-on-giving-up-the-giver-to-hollywood.html? r=0.

Ray, Karen. 31 Oktober 1993. "Children's Book". Diakses pada 1 Mei 2017, dalam alamat http://www.nytimes. com/1993/10/31/books/children-s-books-335293.html.

McLeod, Saul. 2017. "Erik Erikson". Diakses pada 1 Mei 2017, dalam alamat https://www.simplypsychology.org/Erik-Erikson.html 